\title{
APPROACHES OF DENTOMAXILLOFACIAL AND MEDICAL RADIOLOGISTS ABOUT REPORTING
}

Dentomaksillofasiyal ve Medikal Radyologların Raporlamayla İlgili Uygulamalar

\author{
Ilkay PEKER, ${ }^{1}$ Ozlem UCOK, ${ }^{1}$ Aylin KAYADUGUN ${ }^{2}$
}

\author{
Makale Kodu/Article Code : 359037 \\ Makale Gönderilme Tarihi $\quad: 29.11 .2017$ \\ Kabul Tarihi \\ $: 07.03 .2018$
}

\section{öz}

Amaç: Radyolojik raporlama dentomaksillofasiyal radyoloji için görece yeni ve ilgi çekici bir konudur, oysa medikal radyolojide uzun yıllardan beri yapılmaktadır. $\mathrm{Bu}$ çalışmanın amacı, dentomaksillofasiyal ve medikal radyologların radyolojik raporlama ile ilgili uygulamalarını karşılaştırmaktır.

Materyal ve Metot: Dentomaksillofasiyal ve medikal radyologlar çalışmaya e-posta ile davet edildi. Katılımcılar kendi radyoloji raporlarının özellikleriyle ilgili sorulardan oluşan bir anketi doldurdular. Çalışma, dentomaksillofasiyal ve medikal radyologlar olmak üzere iki bağımsız gruptan oluşmaktaydı. Bu iki bağımsız grup için Mann-Whitney U testi yapıldı.

Bulgular: Toplam 285 radyolog (115 dentomaksillofasiyal ve 170 medikal radyolog) çalışmaya katıld1. Hem dentomaksillofasiyal (\%53.9) hem de medikal radyologlar (\%77) tarafindan çoğunlukla yapılandırılmış radyolojik raporlar tercih edilmekteydi, fakat iki grup arasında istatistiksel olarak anlamlı fark bulunamadı $(\mathrm{p}<0.05)$. Dentomaksillofasiyal $(\% 79.1)$ ve medikal radyologlar (\%81.2) çoğunlukla kendi raporlarının klinik bilgi, bulgular ve sonuç olmak üzere ayrı başlıklardan oluştuğunu belirtmekle birlikte, iki grup arasında istatistiksel olarak anlamlı fark vard $1(\mathrm{p}<0.05)$. Dentomaksillofasiyal (\%99.1) ve medikal radyologların (\%99.4) büyük çoğunluğu radyoloji eğitim programlarının radyoloji raporu yorumlamasını da kapsaması gerektiği konusunda hemfikirdi.

Sonuç: $\mathrm{Bu}$ çalışma dentomaksillofasiyal radyologların raporlama uygulamalarıyla ilgili ilk çalışmadır. İyi radyolojik raporlama yapmak dentomaksillofasiyal radyologlar için görece olarak yeni bir görevdir. $\mathrm{Bu}$ çalışma dentomaksillofasiyal ve medikal radyologların radyolojik raporlama ile ilgili uygulamalarının benzer olduğunu gösterdi.

Anahtar kelimeler: Tıp Eğitimi, Radyoloji, Diş Hekimliği, Tıp, Anket

\footnotetext{
${ }^{1}$ Gazi University Faculty of Dentistry, Department of Dentomaxillofacial Radiology, Ankara, Turkey

${ }^{2}$ Suleyman Demirel University Faculty of Dentistry, Department of Orthodontics, Isparta, Turkey
} 


\section{INTRODUCTION}

A radiological report summarizing the radiologic examination is a patient's permanent medical record and it is the most important communication. ${ }^{1}$ The appropriate construction and clarity of the radiological report are essential for high quality patient care as well as the requirement of clinical focus. ${ }^{2}$ Additionally, the radiological report contains prediagnosis and/or diagnosis, a suitably ordered differential diagnosis and, sometimes suggestions for further evaluation. The radiological report also reflects the radiologist's knowledge, skill and training levels. ${ }^{3}$ It can provide multifaceted information about the patient's experience in the radiology department and finalizes with the imaging observations, conclusions, and recommendations. ${ }^{2}$ Communicating the results of imaging procedure to the referring physician and the patient is the primary goal of the radiology report. ${ }^{4}$

The ideal format for the radiology report has not been found and there is no generally accepted format. The presence of wide variety style in reporting may explain this situation. ${ }^{5}$ The radiologists have used two basic forms as traditional free-text and structured reports. Traditional free-text radiology report is dictated in narrative style, any order and format chosen by radiologist. This type of radiology report is mostly non-standardized, deficient, uncertain and error prone. ${ }^{6}$ In recent years, structured reports have replaced traditional free-text radiology reports. ${ }^{7}$ Structured reporting means the use of predefined formats and terms to create reports; in this sense, structured reports are based on templates or checklists. ${ }^{4}$ Radiology report is not only an important communication tool among radiologist and referring clinician, but also a legally binding document. ${ }^{1,7}$ Structured radiology reports include several advantages such as clarity, time-efficiency, automated billing and order entry, presence of technical parameters, measurements, annotations, reduction of ambiguity. ${ }^{4,8}$. Hence, recently, structured radiology reports are preferred by many radiologists and clinicians. Various authors agree regarding many benefits of structured reporting. ${ }^{10-13}$

Recently, the radiological reports are prepared by both medical and dentomaxillofacial radiologists. In dentomaxillofacial radiology, extraoral and intraoral radiographic examinations and especially cone-beam computed tomography (CBCT) images are reported in routine clinical dental practice. Radiology reporting is a relatively new and challenging issue in dentomaxillofacial radiology, whereas radiology reporting has been performed so many years in medical radiology. With the increasing use of CBCT, various necessities have emerged about radiology reporting in dentomaxillofacial radiology. ${ }^{14}$ The approaches of medical radiologists about the reporting are generally well-known. According to best of our knowledge, there is no study about approaches of dentomaxillofacial radiologists.

The purpose of this study was to compare approaches of dentomaxillofacial radiologists and medical radiologists regarding radiology reporting.

\section{MATERIALS AND METHODS}

The study was approved by Gazi University Institutional Review Board (decision number, 77082166/604, 01/02).

The radiologists were invited by e-mail in two separate links via surveey.com, a webbased survey tool for dentomaxillofacial radiologists and medical radiologists to participate the study. Before invitation of the individuals, The Boards of National Oral Diagnosis and Maxillofacial Radiology and Turkish Radiology Society were asked for permissions and their approvals were obtained. The survey contained 15 questions (Appendix). 
All participants both radiologists and residents were considered as radiologists in this study. Responders were asked to enter demographic data and the questions about their radiology reports now.

Statistical analysis was performed by using SPSS software, 23.0 version (SPSS Inc., Chicago, USA). Frequency tables were prepared for all questions and answers. The study was based on basically two independent groups as dentomaxillofacial radiologists and medical radiologists. Mann-Whitney $U$ test was used for two independent groups. $\mathrm{P}$ values of 0.05 were considered to indicate a statistically significant difference.

\section{RESULTS}

In total 285 radiologists (115 dentomaxillofacial and 170 medical radiologists) participated in this survey. The features of the participants including age, gender, academic degrees, relevant institution and examination methods are shown in Table 1. The majority of dentomaxillofacial radiologists was female $(64.3 \%)$ and most medical radiologists was male $(62.9 \%)$.

Table 1. Distribution of demographic information, academic degrees, relevant institution and examination methods of the participants

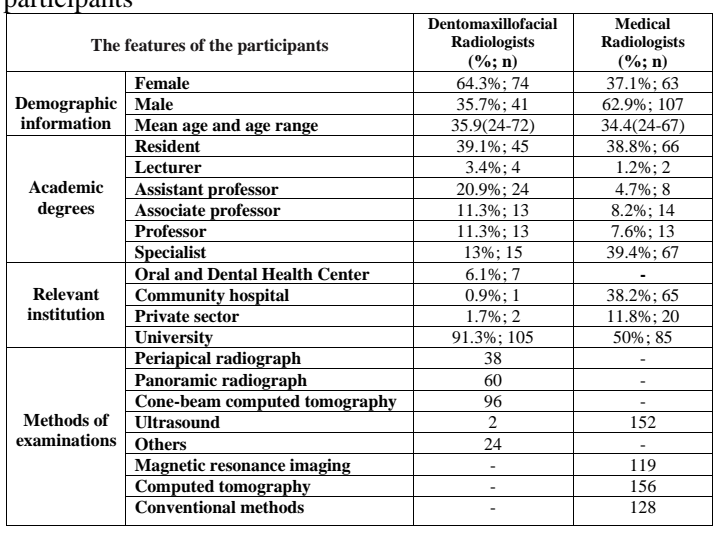

The participation of residents $(39.1 \%)$ was more common in dentomaxillofacial radiologists and specialists (39.4\%) were higher than the others for medical radiologists. The participants for both dentomaxillofacial (91.3\%) and medical radiologists (50\%) mostly worked in universities. The most common examination methods were CBCT and computed tomography for dentomaxillofacial and medical radiologists, respectively (Table 1). Regarding working time in radiology department and reporting time, the majority of both dentomaxillofacial (42.6\%) and medical radiologists (31.8\%) were 1-5 years (Table 2).

Table 2. The distribution of participants for working time in radiology department and their reporting time

\begin{tabular}{|c|c|c|c|c|}
\hline \multirow[b]{2}{*}{ Items } & \multicolumn{2}{|c|}{$\begin{array}{c}\text { Working time in radiology } \\
\text { department }\end{array}$} & \multicolumn{2}{|c|}{ Reporting time } \\
\hline & $\begin{array}{l}\text { Dentomaxillofacial } \\
\text { Radiologists } \\
(\% ; \mathbf{n})\end{array}$ & $\begin{array}{c}\text { Medical } \\
\text { Radiologists } \\
(\% ; \mathbf{n})\end{array}$ & $\begin{array}{l}\text { Dentomaxillofacial } \\
\text { Radiologists } \\
(\% ; \mathbf{n})\end{array}$ & $\begin{array}{c}\text { Medical } \\
\text { Radiologists } \\
(\% ; \mathbf{n})\end{array}$ \\
\hline $\begin{array}{c}\text { I have not written } \\
\text { report }\end{array}$ & 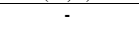 & & $17.4 \% ; 20$ & $1.2 \% ; 2$ \\
\hline $\begin{array}{c}\text { 0-6 months } \\
\text { (including } 6 \text { months) }\end{array}$ & - & $5.3 \% ; 9$ & $7 \% ; 8$ & $5.9 \% ; 10$ \\
\hline $\begin{array}{l}6 \text { month- } 1 \text { year } \\
\text { (including } 1 \text { year) }\end{array}$ & $6.1 \% ; 7$ & $9.4 \% ; 16$ & $13 \% ; 15$ & $9.4 \% ; 16$ \\
\hline $\begin{array}{c}1-5 \text { years } \\
\text { (including } 5 \text { years) }\end{array}$ & $42.6 \% ; 49$ & $29.4 \% ; 50$ & $42.6 \% ; 49$ & $31.8 \% ; 54$ \\
\hline $\begin{array}{c}5510 \text { year } \\
\text { (including } 10 \text { years) }\end{array}$ & $13 \% ; 15$ & $28.2 \% ; 48$ & $12.2 \% ; 14$ & $24.7 \% ; 42$ \\
\hline More than 10 years & $38.3 \% ; 44$ & $27.6 \% ; 47$ & $7.8 \% ; 9$ & $26.5 \% ; 45$ \\
\hline
\end{tabular}

Regarding the sources for writing a good radiology report of the participants during their training (question 6), the majority of dentomaxillofacial radiologists $(43.5 \%)$ reported as teaching staff and medical radiologists reported as more senior trainees (77.6\%). There was a statistically significant difference between two groups $(\mathrm{p}<0.05$; Table 3 ). Regarding the format of radiology report construction, the majority of dentomaxillofacial radiologists and medical radiologists stated that they used the structured report, $53.9 \%$ and $77 \%$, respectively (question 7). A statistically significant difference was found between two groups $(\mathrm{p}<0.05$; Table 3 ). Regarding the use of language in radiology report, the majority of dentomaxillofacial radiologists (60.9\%) and medical radiologists (84.1\%) noticed using common words with clinicians (question 15). There was a statistically significant difference between two groups ( $\mathrm{p}<0.05$; Table 3$)$.

The majority of dentomaxillofacial and medical radiologists reported that patients mostly wanted verbal information about their own findings after examination (question 8). Statistically significant difference was found between two groups ( $\mathrm{p}<0.05$; Table 3$)$. 
Table 3. The comparison between dentomaxillofacial and medical radiologists for sources during radiology training in radiology report construction, report format and language of the report

\begin{tabular}{|c|c|c|c|c|}
\hline Questions & Items & $\begin{array}{l}\text { Dertimauaumuatu } \\
\text { al Radiologits } \\
(\% ; \mathbf{n})\end{array}$ & 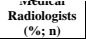 & $P$ value \\
\hline \multirow{5}{*}{$\begin{array}{l}\text { 6. Which sources } \\
\text { did you use during } \\
\text { your training as } \\
\text { radiologist how to } \\
\text { make a good } \\
\text { report? }\end{array}$} & Teaching staff & $43.5 \% ; 50$ & $58.2 \% ; 99$ & \multirow{5}{*}{$0.004^{*}$} \\
\hline & More senior traines & $21.7 \% ; 25$ & $77.6 \% ; 132$ & \\
\hline & Article & $30.4 \% ; 35$ & $36.5 \% ; 62$ & \\
\hline & Courses & $10.4 \% ; 12$ & $34.7 \% ; 59$ & \\
\hline & No education & $33 \% ; 38$ & $4.1 \% ; 7$ & \\
\hline \multirow{3}{*}{$\begin{array}{l}\text { 7. Which format } \\
\text { have you used in } \\
\text { radiology report } \\
\text { construction? }\end{array}$} & Free text format & $39.1 \% ; 45$ & $21.7 \% ; 37$ & \multirow{3}{*}{$0.008^{*}$} \\
\hline & \begin{tabular}{|l|} 
Structured report \\
\end{tabular} & $53.9 \% ; 62$ & $77 \% ; 131$ & \\
\hline & Blank & $7 \% ; 8$ & $1.1 \% ; 2$ & \\
\hline \multirow{3}{*}{$\begin{array}{l}\text { 8. Do the patients } \\
\text { want verbal } \\
\text { information about } \\
\text { findigns after } \\
\text { examination? }\end{array}$} & Often & $25.2 \% ; 29$ & $24.7 \% ; 42$ & \multirow{3}{*}{$0.02^{2}$} \\
\hline & Sometimes & $43.5 \% ; 50$ & $66.5 \% ; 113$ & \\
\hline & Never & $23.5 \% ; 27$ & $8.8 \% ; 15$ & \\
\hline \multirow{3}{*}{$\begin{array}{l}\text { 13. How a language } \\
\text { have you suse when } \\
\text { you write report? }\end{array}$} & I use medical language including radiologic terminology & $38.3 \% ; 44$ & $15.9 \% ; 27$ & \multirow{3}{*}{$0.001^{*}$} \\
\hline & \begin{tabular}{|l|} 
I use common words with clinicians to read the radiology \\
report more easily.
\end{tabular} & $60.9 \sigma_{\%} ; 7_{0}$ & $84.1 \%: 143$ & \\
\hline & 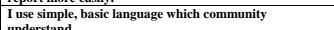 & & & \\
\hline
\end{tabular}

*Difference is statistically significant

Regarding clinical information, findings and the conclusion of the report put into separate paragraphs, most of all participants agreed (question 9). No statistically significant difference was found between two groups ( $>>0.05$; Table 4). The participants mostly reported that their radiology reports ended with a conclusion, included technical details and radiology training programs should include radiology report construction (question 12, 13 and 14). No statistically significant difference was found between two groups $(\mathrm{p}>0.05$; Table 4).

Table 4. The comparison between preferences of dentomaxillofacial and medical radiologists about reporting

\begin{tabular}{|c|c|c|c|c|c|}
\hline \multirow[t]{2}{*}{ Variables } & \multicolumn{2}{|c|}{$\begin{array}{c}\text { Dentomaxillofacial } \\
\text { Radiologists } \\
(\% ; ;) ; n\end{array}$} & \multicolumn{2}{|c|}{$\begin{array}{c}\begin{array}{c}\text { Medical Radiologits } \\
(\% ; \mathbf{n})\end{array} \\
\end{array}$} & \multirow[t]{2}{*}{ P value } \\
\hline & Yes & No & Yes & No & \\
\hline \begin{tabular}{|l|} 
9. Do your radiology reports consist of separate paragraphs \\
such as clinical information, findings and the conclusion? \\
\end{tabular} & $79.1 \% ; 91$ & $20.9 \% ; 24$ & $81.2 \% ; 138$ & $18.8 \% ; 32$ & 0.67 \\
\hline 10. Do your radiology reports end with a conclusion? & $79,1 \% ; 91$ & $20.9 \% ; 24$ & $83.5 \% ; 142$ & $16.5 \% ; 28$ & 0.5 \\
\hline 11. Do your radiology reports include technical details? & 99.1\%; 114 & $0.9 \% ; 1$ & $759 \% ; 129$ & $24.1 \% ; 41$ & 0.9 \\
\hline $\begin{array}{l}\text { 12. Should radiology training programs include radiology } \\
\text { epport construction? }\end{array}$ & $99.1 \% ; 114$ & $0.9 \% ; 1$ & $99.4 \% ; 169$ & $0.6 \% ; 1$ & 0.7 \\
\hline
\end{tabular}

\section{DISCUSSION}

Radiology provides two essential services consisting of imaging procedures and radiologic reports. The centerpiece of a radiologist's communication is based on radiology report. ${ }^{2,15}$ The radiology report is a multifunctional document and invaluable reference for the billing process as well as providing service. ${ }^{15}$ Recently, due to the increasing complexity of medical and dentomaxillofacial radiology practices have resulted in new medicolegal pitfalls. ${ }^{16}$ Therefore, this topic has become more popular among researchers and various studies regarding the satisfactions and reporting practices of radiologists have been performed.
However, these studies have focused on the states and practices of medical radiologists. ${ }^{12,17}$ According to best of our knowledge, this is the first investigation about approaches of dentomaxillofacial radiologists and comparison with medical radiologists.

The radiology residents must learn multiple facets of radiology practice, especially the construction of radiology reports during their training. ${ }^{12}$ However, most of the time there is no specific lecture related with radiology report in the training period. Sistrom et al..$^{18}$ stated that radiology residents received no more than one hour of didactic instruction for radiology reporting per year. Instructions for radiology reporting mostly are based on apprenticeship model. Trainees learn primarily from one-on-one interaction with attending radiologists and more senior trainees in this model. ${ }^{19}$ It has been reported that $98 \%$ of medical radiology residents did not receive any education about reporting, and $78 \%$ of the residents prepared the reports under supervision and guidance of a senior resident. ${ }^{20}$ In this study, $4.1 \%$ of medical radiologists and $33 \%$ of dentomaxillofacial radiologists reported that no education was received related with reporting during their training period. Additionally, $77.6 \%$ of medical radiologists and $21.7 \%$ of dentomaxillofacial radiologists noticed that they prepared the reports in guidance of more senior trainees. The results of this study for medical radiologists about absence of education regarding reporting were different, but about preparation of reports under supervision of a senior resident were very similar to the results of previous studies.

Bosmans et al. ${ }^{12}$ stated that $56.7 \%$ of the radiologists had learned the reporting during their training and Lam et $a l .^{21}$, reported that $83.7 \%$ of the residents said learning is better when teaching others and $86.4 \%$ of them thought teaching opportunities improved their educational experience. All previous studies have been analyzed by medical radiologists 
and/or residents. No study has focused on approaches of dentomaxillofacial radiologists. In this study, approaches of medical and dentomaxillofacial radiologists were compared about reporting. The majority of dentomaxillofacial radiologists remarked that they learned the reporting from teaching staff, whereas most medical radiologists remarked that they learned from more senior trainees. Almost all participants (99\%) agreed about the education of radiology report should be a mandatory part of radiology residency training.

The radiology report is divided into six sections: examination, history/indication, technique, comparison, findings and impressions. This type of report is considered as structured report including paragraphs and headings that distinguish the basic elements of the reports. ${ }^{22}$ Bosmans et al. ${ }^{12}$ reported that most of the radiologists mentioned the use of separate headings for each organ system when reporting complex examinations. Powell et al. ${ }^{17}$ stated that $59.5 \%$ of radiologists were satisfied with their structured report. In another study, most radiologists represented that the reports should occur in separate paragraphs such as clinical information, radiologic findings, conclusion and impressions. ${ }^{12}$ Also, $91 \%$ of medical radiologists stated that a conclusion should be taken at the end of report if it is longer than a few lines. ${ }^{12}$ In the present study, $79.1 \%$ of dentomaxillofacial radiologists and $81.2 \%$ of medical radiologists reported that their own radiology reports consisted of separate paragraphs as clinical information, radiologic findings and conclusion. The results of this study were in accordance with previous studies. ${ }^{12,17,22}$

A radiology report must be dictated in a plain language. Some authors have suggested that it could be understood by the average high school graduate. ${ }^{16}$ However, this condition may be disliked by more experienced and specialized practitioners. ${ }^{16}$ Knowledge and expertise level of the referrer should be considered by the radiologist when the report is constructed. Medical radiologists mostly thought that a radiology report should be easily intelligible, and radiologists should use common words with referrer clinicians. ${ }^{12}$ In the present study, $60.9 \%$ of dentomaxillofacial radiologists and $84.1 \%$ of medical radiologists stated that common words with clinicians were used to read the radiology report more easily. The results of this study were in accordance with previous studies. ${ }^{12,16}$

Alan et $a .^{23}$ emphasized that, most radiologists experienced their patients' request of verbal information after examination. In the same study, $36 \%$ of radiologists thought that verbal information should be given when the patient wants. ${ }^{23}$ In this study, most of all participants reported that patients mostly want verbal information about imaging results. This result was in accordance with previous study. ${ }^{23}$

There were some limitations in the study. Firstly, this study was performed in Turkey and results may vary in different societies. Secondly, the number of medical radiologists was higher than the others, due to the limited number of dentomaxillofacial radiologists.

In conclusion, this is the first study pointing out the approaches of dentomaxillofacial radiologists about reporting. Good radiological report is a relatively new task for dentomaxillofacial radiologists in comparison with medical radiologists. All the radiologists have become more liable to the patients due to increasing malpractice lawsuits in recent years. The results of this study showed that both dentomaxillofacial and medical radiologists were mostly in agreement and their approaches were similar regarding the radiological reports.

All the radiologists concurred for the main topics as listed below:

1. Specific lectures regarding the preparation of good radiologic report should be added to 
the curriculum during training of both medical and dentomaxillofacial radiology expertise.

2. Structured radiologic reports including separate paragraphs such as clinical information, radiologic findings, conclusion and impressions are useful in clinical practice. This type of reports was preferred by both medical and dentomaxillofacial radiologists.

3. The radiologists generally use common words with the clinicians in the reports.

\section{REFERENCES}

1. Turkish Society of Radiology Qualification Board, Standards and Guide Committee, Traditional Radiology Report Written Guideline Document No. 001; 2008.

2. Kahn CE Jr, Langlotz CP, Burnside ES, Carrino JA, Channin DS, et al. Toward best practices in radiology reporting. Radiology 2009; 252: 852-856.

3. Summers JB, Kaminski J. Reporting instruction for radiology residents. Acad Radiol 2004; 11: 1197.

4. Reiner BI, Knight N, Siegel EL. Radiology reporting, past, present, and future: the radiologist's perspective. J Am Coll Radiol 2007; 4: 313-319.

5. Bosmans JM, Weyler JJ, Parizel PM. Structure and content of radiology reports, a quantitative and qualitative study in eight medical centers. Eur J Radiol 2009; 72: 354358.

6. Johnson AJ. Radiology report quality: a cohort study of point-and-click structured reporting versus conventional dictation. Acad is: Radiol 2002; 9: 1056-1061.

7. Hobby JL, Tom BD, Todd C, Dixon AK. Communication of doubt and certainty in radiological reports. Br J Radiol 2000; 73: 999-1001. [s-pep?

8. Iyer VR, Hahn PF, Blaszkowsky LS, Thayer SP, Halpern EF, Harisinghani MG. Added value of selected images embedded into radiology reports to referring clinicians. J Am Coll Radiol 2010; 7: 205-210.
9. Reiner B, Siegel E. Radiology reporting: returning to our image-centric roots. AJR Am J Roentgenol 2006; 187: 1151-1155.

10.Johnson AJ, Chen MY, Swan JS, Applegate KE, Littenberg B. Cohort study of structured reporting compared with conventional dictation. Radiology 2009; 253: 74-80.

11.Plumb AA, Grieve FM, Khan SH. Survey of hospital clinicians' preferences regarding the format of radiology reports. Clin Radiol 2009; 64: 386-396.

12.Bosmans JM, Weyler JJ, De Schepper AM, Parizel PM. The radiology report as seen by radiologists and referring clinicians. Results of the COVER and ROVER surveys. Radiology 2011; 259: 184-195.

13. Ucok O. The importance of reporting in oral and maxillofacial radiology. $\mathrm{J}$ Oral Maxillofac Radiol 2015; 3: 31-32.

14.European Society of Radiology (ESR). Good practice for radiological reporting. Guidelines from the European Society of Radiology (ESR). Insights Imaging 2011; 2: 93-96.

15.Dunnick NR, Langlotz CP. The radiology report of the future: a summary of the 2007 Intersociety Conference. J Am Coll Radiol

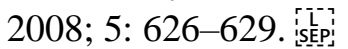

16. Srinivasa Babu A, Brooks ML. The malpractice liability of radiology reports: minimizing the risk. Radiographics 2015; 35: 547-554.

17.Powell DK, Silberzweig JE. State of structured reporting in radiology, a survey. Acad Radiol 2015; 22: 226-233.

18. Sistrom C, Lanier L, Mancuso A. Reporting instruction for radiology residents. Acad Radiol 2004; 11: 76-84

19. Steele JL, Nyce JM, Williamson KB, Gunderman RB. Learning to report. Acad Radiol 2002; 9: 817-820.

20.diagnostic imaging. (homepage on the internet). Howl-Whitney LJ. Radiology reports: are structured systems the answer? RSNA 2013, Diagnostic Imaging, Practice 
Management [updated December 2013]. Available from: http://www.diagnostic imaging.com/rsna-2013/radiology-reports-arestructured-systems- answer?

21.Lam CZ, Nguyen HN, Ferguson EC. Radiology resident' satisfaction with their training and education in the United States: effect of program directors, teaching faculty, and other factors on program success. AJR Am J Roentgenol 2016; 206: 907-916.

22. Sistrom CL, Langlotz CP. A framework for improving radiology reporting. J Am Coll Radiol 2005; 2: 159-167. išp:
23.Alan O, Savc1 G. Preferences of radiologists, clinicians and patients in informing of patients about radiological reports.s. Sepurvey study. $\mathrm{PhD}$, Uludag University Faculty of Medicine, Department of Radiology, Bursa, Turkey, 2012.

\section{Correspondence Author}

Ilkay Peker

Gazi University

Faculty of Dentistry

Department of Dentomaxillofacial Radiology

06510 Emek-Ankara-Turkey

Fax: +90 3122239226

Tel: +90 3122034156

E-mail: drilkaypeker@gmail.com 


\section{Appendix}

The survey

1.Age:

\section{Sex: $\square$ Female $\square$ Male}

3.Institution:
Academic degree: $\square$ Resident
$\square$ Lecturer $\quad \square$ Assistant Professor

$\square$ Associate Professor $\square$ Professor $\square$ Specialist

4. How many years have you worked at radiology department? (including $\mathrm{PhD}$ and specialized)
$\square 0-\leq 6$ month
$\square 6$ month $>-\leq 1$ year
$\square 1>-\leq 5$ years
$\square 5>-\leq 10$ years
$\square$ More 10 years

5 . How many years have you written report?
$\square$ I have not written report
$\square 0-\leq 6$ month
$\square 6$ month $>-\leq 1$ year
$\square 1>-\leq 5$ years
$\square 5>-\leq 10$ years
$\square$ More 10 years

6. Which sources did you use during your training as radiologist how to make a good report?

$\square$ Teaching staff

$\square$ Article

$\square$ More senior trainees $\quad \square$ Course

$\square$ No education

7. Which format have you used in radiology report construction?

$\square$ Free text format

$\square$ Structured report (divided standardizes headings like clinical information, findings, impressions etc.)

8. Do the patients want verbal information about findings after examination?

口Often $\quad$ aSometimes $\square$ Never

9. Do your radiology reports consist of separate paragraphs such as clinical information, findings and the conclusion?

पYes $\quad \square$ No

10. Do your radiology reports end with a conclusion?

$\square$ Yes $\quad \square$ No

11. Do your radiology reports include technical details?

$\square$ Yes $\quad \square$ No

12. Should radiology training programs include radiology report construction?

$\square$ Yes $\quad \square$ No

13. How a language have you use when you write report?

$\square$ I use medical language including radiologic terminology.

$\square$ I use common words with clinicians to read the radiology report more easily.

$\square$ I use simple, basic language which community understand.

14. Which examinations do you report? (for medical radiologists)

DUltrasound $\quad \square$ Magnetic resonance imaging $\quad \square$ Computed tomography $\quad \square$ Conventional methods

15. Which examinations do you report? (for dentomaxillofacial radiologists)

$\square$ Periapical radiograms $\quad \square$ Panoramic Radiograms $\quad \square$ Cone-beam computed tomography

口Ultrasound $\quad \square$ Others (Temporomandibular Joint Graphy, Cephalography etc.) 